\title{
SELF-ASSESSMENT OF AN ORGANISATION ACCORDING TO THE POLISH QUALITY AWARD MODEL ON THE EXAMPLE OF AN AUTOMOTIVE COMPANY - SELF-ASSESSMENT PROCESS, SELECTED IMPROVEMENT ACTIONS
}

\author{
Karol Szewczyk \\ e-mail: karolszewczyk2015@gmail.com \\ ORCID: 0000-0002-9086-1896 \\ (C) 2019 Karol Szewczyk \\ This is an open access article distributed under the Creative Commons Attribution-NonCommercial-NoDerivs license \\ (http://creativecommons.org/licenses/by-nc-nd/3.0/) \\ DOI: $10.15611 / \mathrm{ms} .2019 .1 .06$ \\ JEL Classification: L000, L230, M110
}

\begin{abstract}
The purpose of this paper is to describe the characteristics of organizational self-assessment and its practical use in everyday life. The material presented discusses the process of performance measurement based on examples from the automotive industry. Focus was placed on the model requirements of the Polish Quality Award (PNJ), after the assessment results present the values in each area of the criteria, their potentials for improvement and examples of corrective actions are indicated. The examples contain solutions in the area of communication improvements and employee suggestion programs.
\end{abstract}

Keywords: company self-assessment, continuous improvement, Polish Quality Award (PNJ).

\section{Introduction}

Every year, consumers who are in the market for purchasing a car look for the newest technologies, comfort, better performance, reliability, durability and also visual appearance. Consumers also want all this for the best price possible. Are we sure if such requiments are possible to meet? Do we know if these wants and needs of the consumer are possible to fulfill? Studies show that these results are possible to achieve, however only with the right set of organizational developments regarding the continuous improvement of products and processes. All companies in the automotive market need to be aware of the strong competition offering the same or similar products or technical solutions. Quality is not only beneficial to an organization and a source of profit, but it also supports current performance and sustainable development. This argument is the main reason that original equipment manufacturers in the automotive industry and the suppliers inside the value stream should develop and introduce sufficient systems of quality assurance. How is this possible? One of the proposals will be shown below.

The aim of this article is to present the process of organization self-assessment based upon the model of the Polish Quality Award (PNJ) and performed inside a company within the automotive industry. The results of this research were used to define areas for improvement and examples for organizational solutions.

The first part of the article will answer the questions of what is the self-assessment method of the organization and how will the PNJ model be utilized. At present it is not enough for the organizations to "own" the implemented quality management system which has become the standard. It is necessary to go further by improving the quality management system in accordance with the methodology of the quality awards, for example EFQM and PNJ. Improving quality is a continuous process, not a onetime action and its effects are only noticeable if one 
continues these activities for a long period of time [Wolniak 2014]. A similar approach is presented by K. Szczepańska in her articles: "the contemporary models of comprehensive quality management are divided into relational, descriptive and layered groups. Models of excellence belong to the group of relational models. They are a theoretical construction that results from the observation and generalization of the practice of quality management in enterprises, as well as determining its desirable directions of development. Origin of excellence models come from quality awards, which have now become the standard for comprehensive quality management, because the way in which models of excellence are used by some organizations indicates a reference to the standard of quality management and its improvement" [Szczepańska 2013].

\section{Characteristics of the organization's self-assessment}

Total Quality Management, although similar to other concepts, must be constantly analyzed, verified and adapted to the changing operating conditions of the company. The company's self-assessment tool makes it possible to perform such verification from the point of view of management efficiency [Szpineter, Leśniowska 2000]. How can one understand self-assessment as a management tool? According to Arkadiusz Wierzbic, self-assessment is a comprehensive and regular review of the organization and its results according to the criteria of the adopted model. These results aim at identifying areas for improvement while giving the opportunity to prioritize planned improvement activities that can be regularly be monitored. It follows that the self-assessment model is the evaluation of the current situation in order to introduce improvement changes in the organization [Wierzbic 2013]. A similar definition is used by A. Stefaniecka, in which self-assessment means a systematic, multilateral and comprehensive review of the organization's performance. It allows the identification of strengths and weaknesses. Verification of the latter should lead to actions aimed at improving the entity's functioning, process improvement and the broad use of innovations. An important part of the implementation of a coherent approach to improvement is the preparation of the entire team to conduct self-assessment. A certified quality management model may or may not necessarily be a starting point in the development of the self-assessment methodology. The functions of self-assessment and certification as quality improvement instruments may have many similar aspects. However, they do not coincide and their nature is different. Undoubtedly, their aim should be to strive to improve the broadly understood quality of the organization, not complacency with the achieved state [Stefanicka 2014].

Another author K. Szczepańska in her definition, describes assessment as a valuation opinion which requires the adoption of a specific reference system. For example, regulations (internal or external) can be widely understood or a set pattern (standard, model) adopted by the company may be defined. Self-evaluation is a kind of assessment in which "assessment is done by ourselves", therefore the essence of self-assessment in internal terms corresponds to the evaluation and audit. The concept of self-assessment is related to quality management in both theoretical and normative terms through the principle of continuous improvement. Evaluation, audit and self-assessment are characterized by three parameters: systematic (conducting), purpose (within the meaning of assessing the underlying subject) and activities (organized collection of information and their analysis) [Szczepańska 2013].

Most Polish researchers give a positive feedback on this tool. Self-assessment may concern only the quality management system or the entire organization. The advantage of self-assessment is that it could be implemented within a short timeframe using internal resources. It can be carried out by an interdisciplinary team with the support of top management or by one person in the organization [Borys (ed.) 2012]. Selfevaluation is the valuation of the achievements (results) of the company according to a specific methodology of conduct. Self-evaluation results need to define the use of indicators and measures to assess the degree of achievement of objectives, especially operational management [Szczepańska 2015].

As previously stated, self-evaluation is a comprehensive and systematic (repeatable) review of the organization's activities and its results in relation to the achieved level of maturity of the management system. Any employee of the organization may initiate self-evaluation, however the impulse usually comes from the management or other decision-makers (e.g. owners). In the latter case the acceptance of the team is one of the important factors for the success of the future undertaking. Assimilation of the self-assessment methodology can only take place under conditions of open communication and mutual trust. Without a common understanding of these elements, self-assessment can take a fictitious form, in which case it would not be a useful tool for improving the organization. Self-assessment has an advantage over certification instruments because its implementation does not utilize "pressure" results compliance with the 
model. Its components and frequency of implementation can be flexible and constructed with a holistic approach to combine other models of organizational improvement. Ensuring the coherence of its operation and flexibility of operations is a key challenge that enterprises face today [Stefanicka 2014].

K. Szczepańska states that the application of selfassessment may fulfill the following functions:

- management - using the results of self-assessment in making decisions regarding the management of the quality system,

- information - providing information to the management of the organization,

- motivational - the results of self-evaluation should motivate the managers and employees of the organization to improve the work and its effects on the associates,

- corrective - determination of irregularities in the quality management system and its function,

- stabilizing - continuing the implementation of activities that meets the organization's expectations;

- development - setting future activities aimed at improving quality management.

When using the self-assessment improvement tool, the following principles should be taken into account:

- purposefulness - self-assessment is an intentional activity related to the achievement of its goals by organizations,

- comprehensiveness - self-evaluation concerns all aspects of the organization's function,

- usability - the results of self-assessment are used in the organization management practice,

- continuity - self-assessment results are the basis for future comparisons,

- methodology - self-evaluation is carried out in accordance with the procedure adopted in the organization,

- professionalism - self-assessment is carried out by people who have sufficient knowledge, skills and experience,

- formalization - self-assessment is included in the internal regulations of the organization and its results are an internal document [Szczepańska 2015].

Self-assessment allows the organization to define its strengths and areas for improvement. This process should result in the development of planned activities to improve the organization's work and systematic control.

The development of self-evaluation in the practical activity of the organization brings a number of tangible benefits which can include:

- a disciplined and systematized approach to the problems of improvement activities;
- an assessment based on facts not on individual perception;

- coherence of the directions of activities (proceedings) in determining what should be implemented;

- ways and directions of team training in quality and management issues;

- integrating various pro-quality initiatives into normal operations and processes;

- a very effective diagnosis;

- an objective assessment in relation to a set of criteria widely recognized across Europe;

- measures to evaluate progress over time through periodic self-assessments;

- stimulating action to improve management, focusing on areas where these improvements are most needed, prioritizing;

- rewarding outstanding achievements [Recha 2013].

\subsection{Business Excellence Models (BEM)}

Usage of the self-assessment approach was one of the premise for modern measurement frameworks. They were created and developed by national and international bodies as business excellence models. The reason for this was the global business environment is changing at an unprecedented pace. Scientific research has tried to provide a new understanding to companies around the world of how to better perform in the twenty-first century. This is why new business models and tools have been designed and used in order to make the adaptation easier to this continuous change and to supply relevant performance measurements for any company [Toma, Marinescu 2018, p. 967].

In the literature we can identify one hundred Business Excellence Models and National Quality Awards used across the world, but most researchers have single out three models: the Malcolm Baldrige National Quality Award in the USA (MBNQA), the Deming Prize in Japan and the European Foundation for the Quality Management Excellence Model (EFQM). These models provide guidelines and criteria for evaluation and are used by companies around the world as groundwork for continuous improvement [Talwar 2011, p. 21]. In other words, Models of Excellence help modern organizations measure, predict, monitor the needs and requirements of stakeholders and follow the achievements of other organizations. The results achieved are the basis for the implementation of improvement activities in the organization [EFQM 2013].

According to the study by J. Martusewicz, A. Wierzbic, the use of business excellence models facilitates organizational improvement by obtaining 
an overview of the entire organization, as well as the identification of the organization's strengths and the areas for improvement, enables to check the effectiveness of actions undertaken and to compare it with other organizations, helps with identifying and sharing best practices within the organization, increases engagement of its employees in the continuous improvement or the improvement of internal communication and integration of various pro-quality and improvement initiatives. Such understanding of the models shows them not as an independent practice / concept / method that can be simply applied, but an initiative that allows organizations to convert resources, processes and efforts into specific business results. It is therefore important to know and understand what methods and techniques should be used to improve the organization [Matusewicz, Wierzbic 2018, p. 277].

The research conducted in 2003-2016 shows the better financial performance inside organizations which use excellence models in comparison to similar companies which do not use them. In 10 out of the 15 researched cases there was a statistical correlation between the winner of the Quality Award and business success. There is evidence that companies which introduce excellence models are more effective, efficient and profitable than other companies in the market. There is also a key challenge which is recognized by management: time. Excellence models are not quick fix models of defined areas within an organization, but they concern long-term activities on a strategic and system level [Martusewicz, Szumowski 2018, p. 72].

\subsection{Characteristics of the PNJ Model}

Models of quality awards have been widely described in the literature. In this study, the model of the Polish Quality Award and Regional Awards will be shown (PNJ/RNJ). The purpose of the award is to integrate into the company, mechanisms which ensure the quality of not only the final product evaluated by the market, but also the implementation of the TQM philosophy. This involves organizing and continuously improving the organizational processes so that each activity achieves the highest quality. The model consists of nine criteria which is then divided into two groups the first one to define the potential, and the second to provide the company results. The first group includes leadership in which it describes the commitment of the top management in the implementation of TQM. The vision of the organization is presented by the strategy - a criteria referring to the basic values that guide the company, the directions of its strategy and the manner of their implementation. Employees also play an important role, presenting ways to use human potential. The next two criteria concern partnership and resources as well as the processes that take place in the enterprise. The second group of ratings include customer results and employee results. Important elements include: the impact on the environment, saving natural resources and environmental protection (the results regarding society). The final result of the company's activity is also evaluated [KonarzewskaGubała (ed.) 2006].

Each of the PNJ criteria has specific values that can be expressed in absolute (point) or relative (percentage) values [Szczepańska 2011], as shown in Figure 1.

LEARNING, CREATIVITY AND INNOVATION

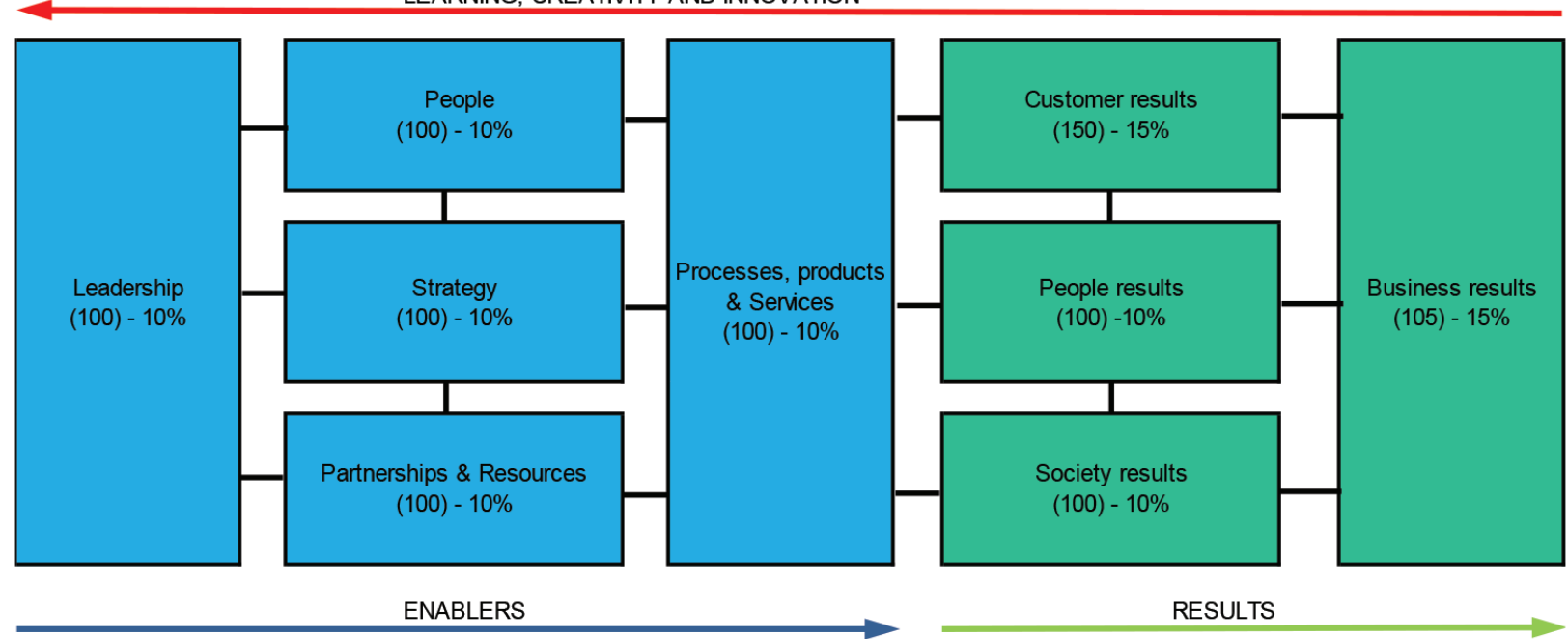

Fig. 1. Polish Quality Award model

Source: [Recha (ed.) 2015]. 
The last element of the model is the RADAR logic. This methodology is common for the PNJ and the EFQM models. In the description of the latter, we can indicate to the organization that it should start by defining the results it intends to achieve as part of its strategy, then plan and create a set of approaches so that the earlier determined results can be obtained. At the next stage, the organization's task is to implement the approach in a systematic manner and finally evaluate and improve the approach used based on the monitoring and analysis of the results achieved and by continuous learning. This tool can give an immediate picture of the company's status and show its continuous improvement [Kacała, Wierzbic 2015].

After reviewing the $\mathrm{PNJ}$ model, please bear in mind its intended use. It should be remembered that the PNJ and EFQM models are tools in which the organization can base the process of improving its management system and achieved results and drive the process to its desired goal, i.e. effective implementation of its own strategy. The model improvement process is based on a systematic implementation of the following cycle: self-evaluation - planning improvement activities - implementing improvement actions. The PNJ model itself is used as a set of appropriately ordered requirements in which the organization refers to in order to achieve a comprehensive self-assessment. In self-assessment it is also necessary to use the RADAR logic as it is a tool to determine the degree of implementation by the organization of individual criteria of the model [Bobik 2011].

The construction of the models (EFQM, PJN) reflects the following assumptions: "Excellent results in terms of business results, customers, employees and society are achieved through leadership as a driving force for policy and strategy that is implemented through employees, partnerships and resources and processes". An important benefit of using models is also the organization's support in the consistent implementation of its mission, vision, strategy and goals. The application of the model also directs the organization to take into account and meet the expectations of all interested parties. Thanks to the models, the management of the organization and all participants of the self-assessment team acquire comprehensive knowledge about the organization and develop their managerial skills. Both managers, employees and the organization as a whole receive new learning opportunities through: participation in training on methods, tools, and introduction of a systematic benchmarking process [Buchacz 2005].

Following that paragraph, it is interesting to take a look at the present winners. In 2017 they were the following companies: Polska Spółka Gazownictwa Sp. z o.o. in the category: a large production organization; DGS Poland Sp. z o.o. in the category: a very large production and service organization; Robert Bosch Sp. z o.o., the branch in Mirków in the category: large production and service organization; Daedong System Poland Sp. z o.o. in the category: large production organization [www.pnj.pl from 05.06.2018].

\section{Examples of the self-assessment process, a case study}

In the second part of the article material from a case study was presented. The self-assessment was carried out by a company in the automotive industry, which is a leading manufacturer of safety components and delivers products and services to premium customers. The assessed plant is part of a larger group, with operations in 22 locations and employs approximately 6 thousand people. Production plants are located in 15 countries in Europe, North America, South America and Asia. It was created in 2012 from the part carved out from a business from another international corporation.

To perform the self-assessment, a team of 12 members was created. The author of this article led the cross-functional team which represented each department in the plant. Software prepared by The Office of Polish Quality Award was used during their work. The results of the self-assessment was shown during the competition for „Dolnośląskiej Nagrody Jakości". Taking part in that contest had the special purpose of comparing the level of company organization within similar companies with the use of benchmarking. Due to the limited size of the article, only part of the submission made by the Wroclaw plant will be shown. The article will present the methodology which was used in order to conduct the self-assessment. Focus points are given to highlight the results in comparison to the PNJ model.

The first pillar of the PNJ model criteria is Leadership. The documentation on this topic is eight pages of the report. This part of the assessment consists of five modules, in which it details that excellent organizations have leaders which shape the future of the organization by implementing it in daily life. They perform model roles that emphasize the organization's values/ethics, and at all times inspire confidence in their stakeholders. They are flexible, allowing the organization to anticipate and respond in a timely manner, ensuring the organization's ongoing success. An assessment of the strengths and weaknesses of the "Leadership" pillar is presented in the tables according to files from the office of the 
Polish Quality Award. Based on the source data which provided objective evidence for the implementation of the guidelines described in the modules, strengths and weaknesses were identified. Next, the assessment of the implementation of the guidelines in percentages, which were converted into points, was carried out. The maximum number of points for each module is 20 . The sum of the number of evaluation points for all modules was 84 out of a possible 100. In the next step the analysis of strengths and weaknesses of the organization was made. In accordance with the presentation of the assessment process, attention will be focused on the results. The prepared documentation was presented to the regional competition PNJ.

A comparison of the analysis' results is presented in Table 1, in which we can find self-assessment prepared by an external expert, based on a review of the documentation which was prepared and assessed during the plant visit. It can be seen that the evaluation carried out by the expert on the basis of the documentation is lower than the self-assessment and the assessment of the visitor's expert. This can be seen in the areas of Employees, Partnerships and Resources and Key Results. The same results were obtained in the module concerning Employee results. On this basis, the first conclusion can already be drawn that in the future, the method of self-assessment should be improved. The areas of improvement should include a coherent description of the solution in the organization, and the benefits and conclusions stemming from the self-assessment of the model.
Table 1. A comparison of assessments criteria according to the PNJ model

\begin{tabular}{|l|c|c|c|}
\hline Model criteria & $\begin{array}{c}\text { Result } \\
\text { of self- } \\
\text { assessment } \\
\text { by plant } \\
\text { [points] }\end{array}$ & $\begin{array}{c}\text { Internal } \\
\text { assessment of } \\
\text { documentation } \\
\text { by PNJ expert } \\
\text { [points] }\end{array}$ & $\begin{array}{c}\text { Expert } \\
\text { assessment } \\
\text { after visiting } \\
\text { the plant } \\
\text { [points] }\end{array}$ \\
\hline 1. Leadership & 84 & 80 & 85 \\
\hline 2. Strategy & 84 & 75 & 82 \\
\hline \begin{tabular}{l} 
3. People \\
\hline $\begin{array}{l}\text { 4. Partnership and } \\
\text { Resources }\end{array}$
\end{tabular} & 89 & 73 & 81 \\
\hline $\begin{array}{l}\text { 5. Processes, } \\
\text { products \& } \\
\text { services }\end{array}$ & 81 & 76 & 72 \\
\hline $\begin{array}{l}\text { 6. Customer } \\
\text { results }\end{array}$ & 120 & 105 & 120 \\
\hline 7. People results & 70 & 70 & 70 \\
\hline 8. Society results & 60 & 60 & 70 \\
\hline $\begin{array}{l}\text { 9. Business } \\
\text { results }\end{array}$ & 109 & 105 & 90 \\
\hline
\end{tabular}

Source: own elaboration.

The presented use of self-assessment brought measurable results indicating areas for improvement. The analysis of the organization's weaknesses identified in the self-assessment and by the auditor who visited the plant are presented in Table 2 .

The defined deviations from the model were clustered because the comments with potentials

Table 2. Areas for improvement identified during self-assessment and highlighted by the PNJ expert.

\begin{tabular}{|c|c|}
\hline Model criteria & Weak points \\
\hline 1 & 2 \\
\hline 1. Leadership & $\begin{array}{l}\text { 1.1. Communication process shall be improved due to relocation process, } \\
\text { 1.2. Simplify data on department boards, they seem to be complicated, } \\
\text { 1.3. Further communication process improvement is recommended, } \\
\text { 1.4. Improvement by simplification of employee suggestion scheme is recommended, } \\
\text { 1.5. Line managers need time for full adjustment. }\end{array}$ \\
\hline 2. Strategy & $\begin{array}{l}\text { 2.1. Improvement of definition methods and assessment of critical processes and it's verification is recommended, } \\
\text { 2.2. Benchmark process improvement is recommended, } \\
\text { 2.3. Further strategy improvement after organization transformation is recommended, } \\
\text { 2.4. Communication process shall be improved due to relocation process. }\end{array}$ \\
\hline 3. People & $\begin{array}{l}\text { 3.1. Survey of employees improvement process is recommended, } \\
\text { 3.2. Improvement of competence matrix to permit objective assessment of production employees competencies is } \\
\text { recommended, } \\
\text { 3.3. Improvement by simplification of employee suggestion scheme is recommended, } \\
\text { 3.4. Communication process shall be improved due to relocation process, } \\
\text { 3.5. Improvement of bonus system and society activities enforcement is recommended. }\end{array}$ \\
\hline $\begin{array}{l}\text { 4. Partnership } \\
\text { and Resources }\end{array}$ & $\begin{array}{l}\text { 4.1. Local target management improvement process is recommended, } \\
\text { 4.2. Improvement process of plant results is recommended, } \\
\text { 4.3. TPM activities improvement is recommended, } \\
\text { 4.4. Some production lines are complicated and could be more flexible, } \\
\text { 4.5. Two-way communication flow, assessment of communication by employees is recommended. }\end{array}$ \\
\hline
\end{tabular}


Table 2, cont.

\begin{tabular}{|l|l|}
\hline \multicolumn{1}{|c|}{} & \multicolumn{1}{c|}{2} \\
\hline $\begin{array}{l}\text { 5. Processes, } \\
\text { products \& } \\
\text { services }\end{array}$ & $\begin{array}{l}\text { 5.1. Improvement by simplification of employee suggestion scheme is recommended, } \\
\text { 5.2. Further innovation improvement system is recommended, } \\
\text { 5.3. Further marketing strategy improvement is recommended, } \\
\text { 5.4. More focus on critical processes, } \\
\text { 5.5. Further improvement of specific customer requirement mindset is recommended. }\end{array}$ \\
\hline $\begin{array}{l}\text { 6. Customer } \\
\text { results }\end{array}$ & $\begin{array}{l}\text { 6.1. Brand recognition improvement is recommended, } \\
\text { 6.2. Communication process shall be improved. }\end{array}$ \\
\hline 7. People results & $\begin{array}{l}\text { 7.1. Systematic employee survey shall be maintained, } \\
\text { 7.2. Communication process shall be improved. }\end{array}$ \\
\hline 8. Society results & $\begin{array}{l}\text { 8.1. Further improvement of the process influencing society is recommended, } \\
\text { 8.2. Further improvement of process with influence on society is recommended. }\end{array}$ \\
\hline 9. Business results & $\begin{array}{l}\text { 9.1. Communication process shall be improved, } \\
\text { 9.2. Further improvement of some process indicators is recommended. }\end{array}$ \\
\hline
\end{tabular}

Source: own elaboration based on the report from the external PNJ auditor.

referred to the same issues, e.g. the improvement of communication is included as a recommendation in the module 1.1, 2.4, 3.4, 7.2, 9.1. Then, preventive actions were proposed. In order to close the PDCA cycle, improvement actions needed to be defined, which will be given in the next section.

\section{Selected corrective actions}

The management gave priority for the improvement of communication, the lack of which was mainly caused by working simultaneously in two buildings: in the new plant and in the location of the previous owner. At the entrance to the plant were information boards showing basic internal data and results from headquarters (daily information on Occupational Safety, for example incidents or accidents at work). The second board presents the quality status, containing information about the customer's view. In cases of a quality claim, we could observe the example Quality Alert. LCD monitors have been installed at the entrances to the production hall displaying important information about visits from headquarters, customer visits, audits and announcements from the plant manager. As part of the improvement actions, the publication of the company newspaper was scheduled for every two months and the frequency of meetings with employees was increased. It is important to highlight the meeting on the "ramp" (this is an unloading area for incoming materials to the plant). The meeting was to take place quarterly and last a maximum of 30 minutes. All employees were to take part in the meeting, which was scheduled in the morning for the third and first shift and in the afternoon for the second shift and administrative departments. A standard agenda for the meeting was proposed, which could be modified as necessary. It contained: the status of health and safety at plant, the plant's priorities for a given year and the status of their implementation (finances - costs, quality, organizational structure, communication, and acquisition projects), answers to employee questions, a summary and conclusion.

It was decided to simplify the employee suggestion system, which had roots in the past as the process was from the previous owner of the company. A task force was set up to develop a new process and document the procedure for the reporting of workers' ideas. The team started with the definition of "employee suggestion" which had to be clear and understood by all the personnel in the plant. It was to be a technical, organizational or financial, improvement that would introduce changes in the practices and solutions applied so far, which would benefit the company. The suggestion was to consist of a description of the current situation and the proposed solution. In the case of ideas with a measurable financial benefit for the plant, it was necessary to attach the initial cost calculation and the profit potential after implementing the idea. The improvement proposal could not come directly from tasks that an employee was required to perform at a given workplace. If the improvement proposal was a task that the employee had imposed from a level above (e.g. goals set by the manager, job description, projects assigned to a given employee, etc.), then it could not be accepted by the assessor of the application - direct supervisor. Ideas created during organized, official optimization workshops, carried out by employees and ideas created during project meetings were not to be considered as improvement ideas.

The abolition of splitting ideas into the traditional meaning (long-term solution) and the quick fix solution 
(how it was done previously) was new. The application for the idea was simplified. It was supposed to be twosided and could be printed on A5 paper, one for every idea. The new system increased the role of the direct superiors (production team leaders) and the managers in the assessment and decision of introducing the ideas, thus shortening the evaluation time of the ideas. Printed forms were placed on each department board in the production area, in the offices and on stands at the entrances to the building. Completed forms were submitted to the idea box which was located in a dedicated place. Additionally, guests, suppliers and customers could place their applications in a mailbox located on a general table of ideas that was located in the canteen. Requests from outsiders were collected and considered by the plant manager. The production team leader/direct supervisor in the department took applications every day and had five working days to evaluate the applications. After evaluation, the applications for implementation were sent to the "In progress" area and stayed there until they were fully implemented. After implementation, the direct supervisor forwarded the applications to the head of the department who awarded points in accordance with the adopted criteria. Rejected applications were sent to the appropriate rejection box, and the author was informed by their immediate superior about the rejection of the application. Ideas regarding significant financial savings were considered individually with the participation of specialists from the controlling department within five consecutive working days. The manager of a given department awarded points after implementation of each idea accepted for implementation according to detailed assessment criteria, as presented in Table 4. Ideas approved for implementation were then introduced in accordance with the individual implementation schedule specified for each application, about which the team leader / direct supervisor informed the author of the proposal. By the 10th of each month, the responsible manager forwarded all rejected applications and conclusions of the ideas that were implemented in the previous month to the system coordinator. Applications in progress remained in the department until the final implementation of the idea. The coordinator supervised the suggestion system and was responsible for the overall functioning of the process. They also ran twomonth rankings of the successful employee scoring and presented them to the employees. Rankings were updated on an ongoing basis on the employee ideas board located in the canteen. Their duties also included archiving applications and maintaining their electronic register. Twice a year, the coordinator reported to the director and heads of departments on the quality and quantity of implemented ideas and the savings that were achieved at that time. Once a week during the daily 10 am meeting, the managers reported on the number of implemented ideas in their departments on an especially prepared table. Every two months the authors were awarded the highest number of points collected for their implemented ideas. Scoring was calculated separately for the production area and office departments.

The new simplified system of employee ideas was designed to support creativity and innovation, the culture of continuous improvement and improve the efficiency of work. It was also the "voice of employees", or another communication channel that

Table 4. Criteria for assessing employee ideas

\begin{tabular}{|c|c|c|c|c|c|c|c|c|c|c|c|c|c|}
\hline \multicolumn{2}{|l|}{ Quality } & \multicolumn{2}{|l|}{ Productivity } & \multicolumn{2}{|l|}{ Working system } & \multicolumn{2}{|l|}{ Innovation } & \multicolumn{2}{|l|}{ Saving } & \multicolumn{2}{|c|}{ HSE /Ergonomics } & \multicolumn{2}{|l|}{ Technology } \\
\hline No influence & 0 & No influence & 0 & No influence & 0 & $\begin{array}{l}\text { Copy of } \\
\text { existing idea }\end{array}$ & 0 & No influence & 0 & No influence & 0 & No influence & 0 \\
\hline $\begin{array}{l}\text { Reduction } \\
\text { of used } \\
\text { elements } \\
\text { or tools }\end{array}$ & 1 & \begin{tabular}{|l|} 
Operation \\
time or \\
material flow \\
reduction \\
\end{tabular} & 1 & $\begin{array}{l}\text { Data or } \\
\text { working } \\
\text { system } \\
\text { standardization }\end{array}$ & 1 & $\begin{array}{l}\text { Improvement } \\
\text { of existing } \\
\text { idea }\end{array}$ & 2 & $\begin{array}{l}\text { Uncountable } \\
\text { or less then } \\
1 \mathrm{k} \text { PLN per } \\
\text { year }\end{array}$ & 1 & $\begin{array}{l}\text { Station or work } \\
\text { organization } \\
\text { improvement }\end{array}$ & 1 & $\begin{array}{l}\text { Material } \\
\text { flow } \\
\text { improvement }\end{array}$ & 1 \\
\hline $\begin{array}{l}\text { Scrap } \\
\text { reduction }\end{array}$ & 3 & $\begin{array}{l}\text { Time or } \\
\text { quantity of } \\
\text { changeover } \\
\text { reduction }\end{array}$ & 4 & $\begin{array}{l}\text { Time/ Material/ } \\
\text { Rework } \\
\text { reduction }\end{array}$ & 3 & New idea & 8 & $\begin{array}{l}1-5 \mathrm{k} \text { PLN } \\
\text { per year }\end{array}$ & 2 & $\begin{array}{l}\text { Working } \\
\text { comfort } \\
\text { improvement }\end{array}$ & 2 & $\begin{array}{l}\text { Line layout } \\
\text { improvement }\end{array}$ & 3 \\
\hline $\begin{array}{l}\text { Reduction } \\
\text { of external } \\
\text { scrap }\end{array}$ & 4 & $\begin{array}{l}\text { Reduction of } \\
\text { operation or } \\
\text { machine }\end{array}$ & 5 & $\begin{array}{l}\text { Non value } \\
\text { added activity } \\
\text { reduction }\end{array}$ & 5 & & & $\begin{array}{l}\text { 5-10k PLN } \\
\text { per year }\end{array}$ & 3 & $\begin{array}{l}\text { Safety } \\
\text { improvement }\end{array}$ & 5 & $\begin{array}{l}\text { Process } \\
\text { improvement }\end{array}$ & 5 \\
\hline $\begin{array}{l}\text { Reduction } \\
\text { of scrap at the } \\
\text { customer's }\end{array}$ & 5 & from process & & & & & & $\begin{array}{l}\text { More than } \\
10 \mathrm{k} \text { PLN } \\
\text { per year }\end{array}$ & 4 & & & & \\
\hline
\end{tabular}

Source: internal materials of the rated company. 
allowed all employees to engage and strengthen the processes taking place in the enterprise. The indicator concerning the number of submissions implemented by an employee was monitored by the department manager. One submitted idea implemented per employee during the year was adopted as a goal.

Another activity was the review of the contents of the departmental tables aimed at analyzing the indicators and the actions presented on them. The purpose of that review is to have a clear connection between the work performed in a defined area and the support functions which have a direct impact on plant targets. The task force dealing with this problem presented its proposals for assessment to the plant manager. Analysis of the functional departments included the status of the self-assessment and proposals for the optimal state prepared by the managers. Based on these reviews, the final decisions were made.

A group of medium-term activities includes the development of environmental and external impact plans. The main idea was that the activities should be undertaken in a thoughtful and sustainable manner, and not only the initiatives of managers or employees from certain departments. Due to the need for continuous improvement, internal activities were focused on conducting an employee survey. This questionnaire was supposed to allow management to get acquainted with employees' opinions that concerned social conditions, their motivation to work, and how to manage a company.

\section{Conclusion}

The article presents the results of self-assessment of the entire enterprise according to the criteria of the Polish Quality Award (PNJ) as a tool for continuous improvement and examples of improvement actions. Based on the analysis of the collected data, the company's orientation towards quality in the organizational culture of the company can be seen. Strong areas concerned leadership, strategy and the employee area. The areas that were assessed worse concerned the company's results and the results of cooperation with their environment, which were illustrated in the form of radar charts. In summary, the research part focused on developing a plan of improvement actions, indicating areas for improvement in the company (Table 3). The main areas to improve are: internal communication, employee ideas system, review of the contents of the tables, cooperation with the environment, company benchmarking and carrying out employee surveys. The listed areas were grouped into tasks, the responsible persons were assigned and the time for implementation was set. For some comments, for example module 4.4 concerning complicated production processes, actions were not taken because they do not have an economic justification. The management gave priority to the following improvement activities: improvement of communication, simplification of the employee ideas system and review of KPIs (Key Performance Indicators) on the department boards. The development of environmental and external impact plans has been defined. They had a thoughtful and long-term method implemented in the company's policy in that area, not only representing the initiative of managers or employees from certain departments. Long-term activities were aimed at benchmarking visits and working with the company's headquarters to increase brand recognition. The internal actions were to be focused on carrying out an employee survey, which was the basis for determining the PDCA activities and areas to be improved.

\section{Bibliography}

Bobik D., 2011, Kryteria modelu doskonatości EFQM 2010, ABC Jakości, no. 1-2.

Borys T., Rogala P. (ed.), 2012, Systemy zarządzania jakościa $i$ środowiskiem, zaktualizowane, Wyd. Uniwersytetu Ekonomicznego we Wrocławiu.

Buchacz T., 2005a, Model EFQM w praktyce, ABC Jakości, no. 4.

Buchacz T., 2005b, Zastosowanie modelu EFQM do doskonalenia organizacji, ABC Jakości, no. 4.

Buchacz T., 2016, Model EFQM w praktyce. Uczenie się Modelu EFQM, ABC Jakości, no. 1.

Kacała J., Wierzbic A., 2015, Od systemów znormalizowanych do doskonałości biznesowej, Management Forum wydawnictwo Uniwersytetu Ekonomicznego we Wrocławiu, vol. 3, no. 4.

Konarzewska-Gubała E. (red.), 2006, Zarzadzanie przez jakość. Koncepcje, metody, studia przypadków, Wydawnictwo Akademii Ekonomicznej im O. Langego we Wrocławiu, pp. 386-387.

Martusewicz J., Szumowski W., 2018, Modele dojrzałości a modele doskonatości. Niezależność czy wspótzależność na drodze do rozwoju organizacji, Organizacja i Kierowanie, no. 1(180).

Martusewicz J., Wierzbic A., 2018, The level of maturity and the use of management methods in business excellence models, Entrepreneurship and Management, vol. XIX, issue 6, part I.

Recha M., 2013, Opis modelu Polskiej Nagrody Jakości (PNJ), Warszawa.

Recha M. (ed.), 2015, Podstawowe dane i kryteria nagród zespolowych oraz wdrazenie modelu i opracowanie samooceny $P N J$, Sekretatiat PNJ.

Stefanicka A., 2014, Samoocena jako model doskonalenia przedsiębiorstwa, Problemy Jakości, no. 1.

Stefanicka A., 2014, Samoocena jako model doskonalenia przedsiębiorstwa, cz. 2, Problemy Jakości, no. 2.

Szpineter J., Leśniowska H., 2000, Polska Nagroda Jakości a Europejska Nagroda Jakości, Problemy Jakości, no. 2. 
Szczepańska K., 2013, Doskonalenie zarządzania jakościa, podstawy, ocena perspektywy, Oficyna Wydawnicza Politechniki Warszawskiej.

Szczepańska K., 2015, Zarządzanie jakościa. Koncepcje, metody, techniki, narzędzia, Oficyna Wydawnicza Politechniki Warszawskiej.

Szczepańska K., 2011, Zarządzanie jakościa. W dążeniu do doskonałości, Wydawnictwo C.H. Beck, Warszawa.

Talwar B., 2011, Business excellence models and the path ahead, The TQM Journal, vol. 23, no. 1.
Toma S., Marinescu G., 2018, Business excellence models: a comparison, Proceedings of the $12^{\text {th }}$ International conference on Business Excellence.

Wierzbic A., 2013, System zarzadzania oparty na znormalizowanych wymaganiach jako czynnik rozwoju $i$ wzrostu matych $i$ średnich, Wydawnictwo Uniwersytetu Ekonomicznego we Wrocławiu.

Wolniak R., 2014, Korzyści doskonalenia systemów zarządzania opartych o wymagania normy ISO 9001:2008, Problemy Jakości, no. 3, pp. 20-21.

\section{SAMOOCENA ORGANIZACJI WEDLUG MODELU PNJ NA PRZYKLADZIE PRZEDSIĘBIORSTWA BRANŻY MOTORYZACYJNEJ - PROCES SAMOOCENY, WYBRANE DZIAŁANIA DOSKONALACEE}

Streszczenie: Celem artykułu jest charakterystyka samooceny organizacji oraz opis jej zastosowania w praktyce. W pracy przedstawiono również proces badania przedsiębiorstwa z branży motoryzacyjnej pod kątem zgodności z wymaganiami modelu Polskiej Nagrody Jakości (PNJ). Przytoczono ponadto wyniki osiągnięte w poszczególnych kryteriach modelu, wskazano obszary do poprawy oraz przedstawiono przykładowe rozwiązania z zakresu komunikacji i systemu pomysłów pracowniczych.

Słowa kluczowe: samoocena organizacji, ciągłe doskonalenie, model Polskiej Nagrody Jakości (PNJ). 